\title{
O MICRO E O MACRO: ORIGENS E ASSENTAMENTOS MIGRATÓRIOS NA CONTEMPORANEIDADE
}

\author{
EL MICRO Y MACRO: ORÍGENES Y " ASENTAMIENTOS " MIGRACIÓN EN \\ CONTEMPORÁNEO
}

\author{
${ }^{1}$ Deisemara Turatti Langoski \\ ${ }^{2}$ Geralda Magella de Faria Rossetto
}

\section{RESUMO}

Este artigo tem por objetivo analisar a mobilidade migratória, preconizada nas origens e assentamentos, com a adoção de dois pontos de particular relevância a ser empreendida: o marco familiar e o marco global. O intento levou a escolha da díade micro e macro, com referência à influência decorrente do apoio familiar ao fenômeno migratório, no caso do micro, e, quanto ao macro, o desígnio fora tomado com o intuito de identificar, os motivos pelos quais estão sendo estabelecidos, os novos processos migratórios na contemporaneidade, em contraponto com as premissas dos Direitos Humanos. Neste caso, tanto a clivagem desses direitos, quanto seus fluxos seguirão observados sob a perspectiva da agenda do Haiti, quanto à proteção, promoção e defesa dos Direitos Humanos no processo de globalização, na exata correspondência da dinâmica do cuidado com o próprio ser humano. Neste aspecto, traz-se a questão da desconfiança e do desprezo para com o Outro, tão disfarçados quanto reais, a dissimulação, o preconceito, a discriminação, a não inclusão dos imigrantes nas políticas públicas brasileiras, carecendo deste modo, de reconhecimento, o estatuto jurídico dos migrantes, e, sobremaneira de especial amparo, promoção e defesa dos Direitos Humanos, independentemente de raça, cor ou nacionalidade.

Palavras-chave: Mobilidade migratória, Globalização, Direitos humanos

\section{RESUMEN}

Este artículo tiene como objetivo analizar la movilidad migratoria, abogó por los orígenes y "asentamientos" con la aprobación de dos puntos de especial relevancia para ser llevadas a cabo: el punto de referencia familiar y el marco global. El intento tuvo la elección de la díada "micro y macro", en referencia a la presión de apoyo a la familia con el fenómeno migratorio, en el caso de "micro" y en el "macro", el diseño fue tomada con el fin de identificar, las razones se están estableciendo, los nuevos procesos migratorios en la época contemporánea, en contraste con los supuestos de los Derechos Humanos. En este caso, tanto la división de esos derechos, ya que sus flujos siguen observaron desde la perspectiva de la agenda de Haití, para la protección, promoción y defensa de los derechos humanos en el proceso de globalización, la coincidencia exacta de la dinámica de atención con el ser humano. En este sentido, trae a colación la cuestión de la desconfianza y el desprecio por el otro, como disfrazada como real, el ocultamiento, el prejuicio, la discriminación, la exclusión de los inmigrantes en las políticas públicas de Brasil, a falta de este modo de reconocimiento, condición jurídica de los migrantes, y la protección muy especial, la promoción y defensa de los derechos humanos, sin distinción de raza, color o nacionalidad.

Palabras-claves: Movilidad migratoria, La globalización, Derechos humanos

1 Doutoranda em Direito pela Universidade Federal de Santa Catarina - UFSC, Florianópolis, (Brasil). E-mail: tutortreinamento@gmail.com

${ }^{2}$ Mestre em Direito Universidade do Vale do Rio dos Sinos - UNISINOS, São Leopoldo, Rio Grande do Sul, Brasil. Pesquisadora do Núcleo de Pesquisa de Direito e Fraternidade da Universidade Federal de Santa Catarina - UFSC, Florianópolis, Santa Catarina, Brasil. E-mail: tutortreinamento@gmail.com 


\section{INTRODUÇÃO}

Este estudo tem como escopo examinar os fluxos migratórios, indicados no presente sob a denominação de origens e "assentamentos" seguindo os elementos de sua formação no contexto contemporâneo. Adota-se, para tanto, dois pontos de particular relevância à análise a ser empreendida: o marco familiar e o marco global.

O propósito em comento levou a seleção da díade "micro e macro", conforme assinalada no título, com clara referência à influência decorrente do apoio familiar ao fenômeno migratório, no caso do "micro", e, quanto ao "macro", o objetivo fora tomado com a finalidade de identificar as razões pelas quais estão sendo construídos os novos processos migratórios e de que maneira os mesmos buscam conferir expressão aos arranjos migratórios dispostos na cena global.

Cumpre destacar que há expressa referência a algumas categorias, as quais são citadas no texto, e visando identificar a compreensão que o estudo pretende dar a tais palavras, convém o registro, sentido e distinção das mesmas:

a) Refugiado: a definição de tal expressão está amparada na Convenção de 1951 que dispõe sobre o Estatuto dos Refugiados. O conceito também compreende o conceito contido na Declaração de Cartagena de 1984 que inclui a "violação generalizada de Direitos Humanos" como justificativa para reconhecimento da condição de refugiado. Assim, é dito refugiado aquele que se encontra fora do seu país em decorrência de fundado temor de perseguição por motivos de raça, religião, nacionalidade, opinião política ou participação em grupos sociais, e que não tem a intenção (ou não queira) voltar para casa. ${ }^{1}$

b) Imigrante: é todo aquele que imigra de seu local de origem vindo a se estabelecer em outra região ou país diferente do seu. Saliente-se que a motivação para tanto não se faz necessariamente em decorrência de temores ou perseguições políticas ou religiosas.

c) Apátrida: pertencem a esse grupo, as pessoas que nascem sem nacionalidade ou que têm sua nacionalidade retirada pelo Estado, e, deste modo, ficam sem proteção de um Estado nacional.

1 Sabe-se que, nos dias atuais, outras definições seguiram sendo adotadas e incorporadas ao grupo dos refugiados, quais sejam, as pessoas que se veem obrigadas a deixar seu país em decorrência de conflitos armados, violência generalizada e violação dos Direitos Humanos. 
d) Fenômeno Migratório: compreende a dinâmica que integra o processo de migração de uma região para outra, inclusive o estabelecimento em determinada região ou país.

e) Globalização: o sentido da globalização adotado, refere-se a um sistema de trocas concernentes à política, mercado, economia, comércio, indústria e produção, ainda que submetida a processo local, ou regional, mas que se presta a uma escala global. O processo da globalização facilita e compreende medidas que facilitam a interação social e política entre instituições e pessoas de todo o mundo.

A partir de tais indicações, a presente reflexão será examinada em contraponto com as premissas dos Direitos Humanos, estando os mesmos em contato com a mobilidade migratória. Neste caso, tanto a clivagem desses direitos, quanto seus fluxos seguirão examinados sob a perspectiva da agenda do Haiti, que na fase atual produziu um vigoroso exemplo de proposta de globalização fundada na cooperação e na relacionalidade (basta dizer que o Estado brasileiro enviou tropas e ajuda àquele País), o que confere o tom da proteção, promoção e defesa dos Direitos Humanos no processo de desenvolvimento global na exata correspondência da dinâmica do cuidado com o próprio ser humano.

Norteadores dos objetivos propostos, o presente estudo será dividido em três partes, assim distribuído: na primeira delas serão estudados os Direitos Humanos e processos de globalização, tendo como pano de fundo a tríade (proteção, promoção e defesa) dos Direitos; na segunda parte, será analisada a Agenda dos Direitos Humanos, tendo como perspectiva a mobilidade migratória. Na terceira e última parte, serão examinados os espaços de regulação migratória visando destacar o marco regional familiar e o global, contrapondo a dinâmica que está sendo desenhada na atualidade.

Com efeito, é tarefa primordial deste, identificar e localizar a gramática da proteção, promoção e defesa dos direitos dos migrantes, na medida em que dependente dos parâmetros internacionais, por mais que afeita a uma realidade nacional local são os documentos expressos nas seguintes declarações e tratados que reafirmam a tônica de reconhecimento desses direitos: a Convenção das Nações Unidas sobre o Estatuto dos Refugiados de 1951; o Protocolo das Nações Unidas de 1967; a Declaração de Cartagena de 1984; a Convenção das Nações Unidas sobre Trabalhadores Migrantes de 1990 e as Convenções da OIT sobre Trabalhadores Migrantes (Convenções n. 97/1949 e n. 143/1975). Há ainda, pela pertinência, ser incluída a Convenção sobre Refugiados da Organização da Unidade Africana de 1969. Estes documentos compõem o espectro dos 
direitos dos migrantes e são merecedores de destaque, independentemente dos padrões de migrações: se as emigrações acontecem para outras regiões, ou se trata de migrações intraregionais, sem, contudo, esquecer: a principal motivação para a migração regularizada para outras regiões consubstancia-se na reunião dos laços familiares.

\section{DIREITOS HUMANOS E PROCESSOS DE GLOBALIZAÇÃO: A TRÍADE DA PROTEÇÃO, PROMOÇÃO E DEFESA DOS DIREITOS}

Os Direitos Humanos foram recepcionados, na era contemporânea, a partir da compreensão de que suas características evoluíram de um simples direito humano individual, para um direito humano amplo, que abrange interesses difusos, transindividuais e coletivos. Não é de se desprezar o fato de que a partir da década de 90, os relatórios das Nações Unidas têm apresentado tais direitos na dimensão do ser humano, "para" o ser humano e "pelo" ser humano.

Consubstanciam-se, os Direitos Humanos, como o resultado de lutas sociais incessantes por direitos e apresentam-se associados a desenvolvimentos históricos iniciados tanto na América do Norte quanto na Europa.

Ao longo do presente século, muitas foram as ações públicas e privadas voltadas para a afirmação dos Direitos Humanos. Contudo, foi com o advento do Tratado de Versalhes (1919) que a ideia de um direito global, comum, inerente a todos os povos foi difundida internacionalmente.

O marco para a afirmação dos Direitos Humanos foi a fatídica Segunda Guerra Mundial, que teve como premissa negar regimes totalitários e promover a prática de democracias voltadas à consideração e o respeito pelo homem. A Declaração Universal de Direitos do Homem e do Cidadão foi produto de intenso empenho da comunidade internacional e decorreu da compreensão e da consciência humana pós a $2^{\mathrm{a}}$ Guerra Mundial, a qual se acometeu em firmar entendimentos sobre direitos, abarcando os que deveriam receber proteção e defesa.

Outra noção emanada da influência internacional foi a de que todo indivíduo é dotado de autonomia, representado pela sua liberdade individual. Com tal condão, valorizou-se o homem como ser social, independentemente de qualquer variável externa por exemplo, política, social, e religiosa - é um ser dotado de subjetividade singular, e por tal condição deve ser respeitado. 
O reconhecimento internacional desses acordos, tratados e declarações e sua respectiva positivação dentro do rol de normas de cada país contribuiu para que as violações aos Direitos Humanos fossem incluídas na recepção normativa doméstica, e se for o caso, no elenco da tipicidade criminal, o que possibilitou avanços ao exercício de tais direitos.

Resultante de construção histórica, movimentos sociais e consequentes lutas, o desdobramento e a legitimidade dos Direitos Humanos, forçam a acreditar que o futuro que se lhe apresentam está na dependência da continuação de movimentos e ações capazes de assegurar sua permanência, sobretudo, no reconhecimento de sua universalidade e indivisibilidade. Esclarece González (2006, p. 179),

[...] é necessário reconhecer que os Direitos Humanos, como a democracia, são construções humanas e poderão existir de acordo com a mobilização e a interferência de todos os seres humanos para concretizá-las. São construtos políticos, fundados em valores e instituições que dependem da ação humana.

Dessa forma, sua caracterização coliga-se à organização da comunidade sóciopolítica e histórica, deste modo, é problemático atribuir uma dimensão permanente, nãovariável e absoluta para direitos que se revelaram historicamente relativos.

Afirma-se que o desenvolvimento da teoria e da prática dos direitos do homem, a partir do final das guerras mundiais, aponta em duas direções: na universalização e na sua multiplicação e a decorrente transformação do direito das "gentes" em direito dos indivíduos, os quais adquirem o direito de questionar o seu próprio Estado, e vão se transformando de um estado particular, em cidadãos do mundo (BOBBIO, 1992, p.68).

O conceito dos Direitos Humanos foi concebido em torno do pós-guerra, notadamente, em resposta aos horrores do Nazismo, com a Declaração Universal de 1948 e a Declaração de Direitos Humanos de Viena (1993). A sua definição primeira, construída em torno da pessoa humana - o homem -, e após passa-se à noção de proteção, promoção e defesa de tais direitos, representativos da Declaração Universal.

Bobbio (1992, p. 25) refere que "o problema grave de nosso tempo, com relação aos direitos do homem, não era mais o de fundamentá-los, e sim o de protegê-los”.

A construção moderna dos Direitos Humanos, propiciada pela cumulação de tratados internacionais e pelo aprimoramento dos mecanismos de monitoramento e promoção, implicou o surgimento de características próprias que informam sua compreensão, direcionando a interpretação de suas normas no sentido de sua máxima 
efetividade, porém, recorrem a um processo histórico, sem o qual, impossível a sua concepção, abrangência e percepção.

Martinez (1993, p. 23), refere que "los derechos humanos son um concepto histórico y que no puedem entender plenamente prescindiendo de los materiales que la história nos proporciona".

Da mesma maneira, se a concepção jurídica, normatizada, não contemplasse a construção histórica, certamente muito mais difícil seria a sua proteção. Na Declaração e no Programa de Ação adotada pela Conferência Mundial sobre Direitos Humanos (Viena, 1993), consta:

5. Todos os Direitos Humanos são universais, indivisíveis interdependentes e inter-relacionados. A comunidade internacional deve tratar os Direitos Humanos de forma global, justa e equiitativa, em pé de igualdade e com a mesma ênfase. Embora particularidades nacionais e regionais devam ser levadas em consideração, assim como diversos contextos históricos, culturais e religiosos, é dever dos Estados promover e proteger todos os Direitos Humanos e liberdades fundamentais, sejam quais forem seus sistemas políticos, econômicos e culturais.

A concepção universal dos Direitos Humanos decorre da ideia de inerência, e significa que tais direitos pertencem a todos os membros da espécie humana, sem qualquer distinção fundada em atributos intrínsecos aos seres humanos ou da posição social que ocupam. Para González (2006, p.179), “os Direitos Humanos não se tornarão universais somente porque dizemos que são universais. Não serão indivisíveis porque existe uma proclamação que os identifica desta forma".

Do mesmo modo, o preâmbulo da Declaração Universal dos Direitos Humanos, no seu primeiro parágrafo, reconhece a "dignidade inerente a todos os membros da família humana e seus direitos iguais e inalienáveis é o fundamento da liberdade, da justiça e da paz do mundo". Referida acepção é representativa da noção de que os direitos atinentes a cada pessoa, pelo simples fato de sua existência, decorrem do fundamento jus naturalista racional adotado pelo Direito Internacional dos Direitos Humanos.

Em um mundo cuja proteção internacional dos Direitos Humanos é ingrediente essencial de governabilidade mundial, referida proteção serve de parâmetro para todos os governos da comunidade internacional (RAMOS, 2001, p.37-38).

Forte na prerrogativa de que há muitos e diferentes povos com culturas únicas e singulares, a doutrina de Direitos Humanos encerra uma moralidade com um mínimo de padrão moral, e não um sistema moral amplo (FREEMAN, 1998, p. 8), sendo certa a promoção e a proteção de condições mínimas de vida digna. 
No que se refere à globalização, esta não se trata de nenhuma conspiração dos americanos, japoneses ou de outros sombrios poderes, mas sim, um resultado do desenvolvimento tecnológico econômico da era moderna na Europa (KUNG, 1999, p. 279).

A globalização é considerada como um modelo complexo, de largo alcance, porque coloca tudo e todo em rede de trocas, identificadora dos interesses do capitalismo, quer nacional, quer internacionais, especialmente, a força dos meios de comunicação.

Poucos períodos na história puderam traduzir tão bem a importância da universalidade dos Direitos Humanos na esfera das relações internacionais entre as Nações e os povos como a globalização, e para a qual, também, o respeito pela legalidade internacional representa um dos legados mais louváveis do século XX. Também, não se pode desconsiderar o fato de que "a globalização econômica tem agravado ainda mais as desigualdades sociais, aprofundando-se as marcas da pobreza absoluta e da exclusão social" (PIOVESAN; IKAWA, 2007, p. 27).

Da mesma forma,

É inadmissível que continuem a ser negligenciados em nossa parte do mundo, como o têm sido nas últimas décadas, os direitos econômicos, sociais e culturais. O descaso com estes últimos é triste reflexo de sociedades marcadas por gritantes injustiças e disparidades sociais (TRINDADE, 1999, p. 40)

Partindo da premissa de sua universalidade, e por tabela, para a ideia de Direitos Humanos universais ameaçados pelo relativismo cultural (FREEMAN, 1998, p. 11), e neste caso se fala de Direitos Humanos "nacionais", consignam-se diversas concepções de Direitos Humanos dentro e entre os países.

Ademais, "o processo de mundialização, como preferem os franceses, ou globalização econômica implica em uma radical mudança no perfil do Estado contemporâneo, particularmente em seu caráter soberano" (MORAIS, 2001, p.58).

Por mais que se premie a persistência de algumas identidades nacionais, frente à globalização, é forçoso concluir no sentido de que a cultura - e isto também serve para a religião - tem sido alvo de inúmeros conflitos, ou pelo menos representa a porta de entrada, para a instalação de processos de não paz, de intolerância, de dissabores crescentes, da disseminação de discórdias, de desordens nacionais que repercutem na ordem internacional, enfim, de processos instauradores de violações de Direitos Humanos que maculam a sua efetividade. 
A concretização da proteção, promoção e defesa dos direitos do homem, estão ligadas ao desenvolvimento global da civilização humana. Se isolado, pode não ser resolvido, e sequer ser compreendido. Não se pode por o problema dos Direitos Humanos, abstraindo dos grandes problemas da guerra e da miséria, da potência que gerou a guerra e o excesso de impotência que condena a fome (BOBBIO, 1992, p. 45).

Do mesmo modo, é preciso que se compreenda que no contexto dos Direitos Humanos, há uma conduta política; existe um comportamento jurídico para a promoção, interpretação e violação dos Direitos Humanos; e possui um procedimento, cujos efeitos, têm a influência do processo global econômico, da mesma forma que a compreensão dos Direitos Humanos pode se dar pelo viés da universalidade, ou da multiculturalidade, cuja resposta, dependente de uma conduta político-social esperada, voltada para a regulamentação e traduzida: das pessoas (capacidade e oportunidade); para as pessoas (equidade e dimensão); pelas pessoas (empoderamento); e, para e pelos outros (equanimidade, amorosidade).

Em seguida, trata-se de elucidar a ampliação da mobilidade migratória no Brasil, especialmente na última década, oriunda de países africanos e caribenhos, sendo a situação dos imigrantes haitianos o objeto peculiar deste estudo.

\section{A AGENDA DOS DIREITOS HUMANOS: TRADUZINDO A MOBILIDADE MIGRATÓRIA PELO VIÉS DO HAITI}

A partir da década de 90, centenas de migrantes chegaram ao Brasil de forma vagarosa e ininterrupta. As poucas informações que se tinham dos mesmos, na grande maioria das vezes, ou eram pejorativas, como o trabalho análogo a escravo, ou eram dados estereotipados quanto à história, literatura, música ou gastronomia (VENTURA; REIS, 2014).

Em face da crise europeia, da mesma forma houve a ampliação dos migrantes daquele continente. No entanto, foi a maciça vinda de migrantes negros, que ocasionou uma maior atenção para a política migratória brasileira e esta entrasse na pauta de amplas discussões, colocando sempre a migração como "problema" ou "crise" a resolver, aduzem Ventura e Reis (2014). Continuam as autoras, dando ênfase ao tema, expondo que:

"Fechar as fronteiras" para a imigração em um contexto de intensa mobilidade humana e enorme desigualdade entre os países não tem ajudado a diminuir as 
migrações, apenas tem ajudado a tornar os trabalhadores imigrantes mais vulneráveis à exploração e ao preconceito.

Como o Brasil não apresenta conflitos aparentes ou maiores tensões socioeconômico, os migrantes veem o país como uma potência emergente, com perspectivas para alcançar uma melhor condição de vida, se comparado às situações adversas e de miserabilidade em que viviam. Este motivo por si só, hodiernamente, tem intensificado as mobilidades migratórias, nos últimos anos, para as diversas regiões brasileiras, notadamente, naquelas que oportunizam e requerem forças de trabalho.

Ademais, a falta de investimentos brasileiros, em políticas públicas migratórias, aparelhando os Estados-membros que possuem fronteiras internacionais, seja com a questão de pessoal no controle e fiscalização ou em medidas restritivas para regular a entrada de pessoas no Brasil, constitui-se em fatores facilitadores deste fenômeno.

Faz-se necessário contextualizar o advento da relação entre os países do Brasil e Haiti, para a compreensão da mobilidade migratória dos cidadãos daquele país para terras brasileiras.

Desde junho de 2004, tropas militares brasileiras encontra-se no Haiti, em força de paz, cujo objetivo consiste na estabilização do país ${ }^{2}$, após um tempo de insurgência e a queda do presidente Jean-Bertrand Aristide.

Em 12 de janeiro de 2010, um terremoto catastrófico de magnitude 7 graus na escala Richter, ocasionou grandes prejuízos a Port-au-Prince, Jacmel e outros locais do estado haitiano. Uma infinidade de edifícios públicos e privados, incluindo inúmeros patrimônios históricos e arquitetônicos da capital, como o Palácio Presidencial, o edifício do Parlamento, a Catedral de Notre-Dame de Port-au-Prince, a prisão mais importante do Haiti, além de todos os hospitais, ficaram completa ou parcialmente destruídos. O fatídico evento vitimou mais de 200.000 pessoas, outras aproximadamente 300.000 pessoas ficaram feridas e aproximadamente 1.600 .000 pessoas ficaram desalojadas (ZAMBERLAM, 2014, p. 25).

Além disso, o Haiti é considerado o país mais pobre do continente americano, e avaliado como uma nação vulnerável economicamente. Revela o relatório do Programa das

2 Em de 30 de abril de 2004, o Conselho de Segurança das Nações Unidas, por meio da Resolução 1542, criou a Missão das Nações Unidas para a Estabilização no Haiti (MINUSTAH), cujos objetivos são: 1. Estabilizar o país; 2. Pacificar e desarmar grupos guerrilheiros e rebeldes; 3. Promover eleições livres e informadas; 4. Formar o desenvolvimento institucional e econômico do Haiti. Por ter o maior contingente, o Brasil, assumiu a coordenação da MINUSTAH. 
Nações Unidas para o Desenvolvimento - PNUD, 2011, que esta situação é agravada pela situação da extrema pobreza, com os imensos desafios ambientais e as enormes desigualdades sociais (ZAMBERLAM, 2014, p. 27).

Em face da presença dos brasileiros na missão paz, desencadeou-se um processo de grande simpatia do povo haitiano pelos brasileiros. Houve também, a declaração de apoio humanitário das autoridades brasileiras e a afirmação de acolhimento no Brasil para os haitianos que desejassem emigrar para terras brasileiras (ZAMBERLAM, 2014, p. 31).

A vinda de milhares de haitianos para o Brasil mobilizou a população e as autoridades públicas e privadas brasileiras, para a matéria das migrações. Não que isso seja um fenômeno novo por aqui, o que existe de inovação, como se pontuou anteriormente, é o aumento do fluxo migratório de pessoas negras, sejam haitianos ou africanos.

Elucidam Ventura e Reis (2014) que "Enquanto o migrante se desloca por vontade própria, quase sempre em busca de trabalho e vida digna, o refugiado teme por sua integridade física e moral caso permaneça em seu país de origem".

Mesmo que os migrantes conquistem um emprego no Brasil, não obterão a garantia da regularização migratória, uma vez que para legislação brasileira, o Estado tem toda discricionariedade. Esclarecem Ventura e Reis (2014), que para os imigrantes, o respaldo legal encontra-se no Estatuto do Estrangeiro (Lei n. 6.815), firmado pelo então General João Figueiredo em 1980, em plena ditadura civil-militar brasileira (1964-1985), que possui como principais particularidades “[...] o alto grau de restrição e burocratização da regularização migratória, a discricionariedade absoluta do Estado, a restrição dos direitos políticos e da liberdade de expressão, além de explícita desigualdade em relação aos Direitos Humanos dos nacionais."

A vigente lei de migrações, não admite aos estrangeiros que estão à procura de emprego ou que trabalhem na informalidade, que continuem de forma regular no Brasil, motivos estes que, colaboram para que muitos imigrantes requeiram o refúgio, com o intuito de possuir algum documento - nem que seja o protocolo da solicitação -, com a expectativa de se colocar no mercado de trabalho e aumentar as probabilidades de permanecer no Brasil.

Depois de muitos contratempos o Ministério da Justiça, com a oitiva de instituições públicas e entidades sociais envolvidas na questão migratória no Brasil, exibiu um anteprojeto de lei de migrações (PLS 288/2013). Destacam-se algumas considerações deste instrumento: consigna que o termo estrangeiro é trocado por migrante, além disso, 
expõem Ventura e Reis (2014) que, o ideário da segurança nacional oferece espaço às disposições da Constituição Federal de 1988 e os tratados internacionais de Direitos Humanos, vigentes no Brasil. Ainda, consta a existência de uma regularização migratória desburocratizada, facilitando a permanência do migrante pelo período de no máximo um ano, desde que esteja em busca de emprego, configurando um processo de regularização migratória desburocratizada. E também, o equilíbrio entre os direitos previstos na Constituição Federal entre nacionais e não nacionais.

Ressaltam Ventura e Reis (2014):

\begin{abstract}
As migrações constituem um terreno privilegiado para que o Brasil se transforme num novo tipo de potência, abrangendo em suas políticas públicas os migrantes, e deles colhendo, mais do que seus impostos e sua força de trabalho, sua extraordinária riqueza cultural. A que sabemos discernir facilmente nos europeus pobres que aqui aportaram no passado, assim como os ricos que hoje chegam, mas que nossos preconceitos, também importados, dificultam que a reconheçamos naqueles que mais se parecem conosco.
\end{abstract}

A seguir, exploram-se os fenômenos migratórios, assentando a questão da diversidade cultural aliada à econômica, como um dos fatores que movimentam as pessoas a sair de sua nação para adentrar em outros espaços culturais, alheios a toda a gama de variações - seja linguística, religiosa, educacional, econômica, social, etc. -, como já frisado, o presente estudo, está centrado na mobilidade migratória dos haitianos. Deste ponto micro, assinalase o obstáculo, que em uma condição macro, atinge frontalmente o enlevo dos migrantes em face do legado originado historicamente e transversalmente pelos reveses do feito da globalização.

\title{
3 OS ESPAÇOS DE REGULAÇÃO MIGRATÓRIA E A BUSCA DE ESPECIFICIDADES CULTURAIS: DO MARCO REGIONAL FAMILIAR AO MARCO GLOBAL
}

Objetivando examinar a temática ora proposta, há de se ter em conta o contexto que serve de base ao fenômeno migratório. $\mathrm{O}$ assentamento migratório não resta pronto e sim por vivenciar. Com efeito, indicam-se dois pontos que reputa-se de fundamental importância ao estudo empreendido: o primeiro, diz respeito à população submetida aos efeitos do conjunto dos atos migratórios; o segundo, refere-se ao espaço relacional, do Outro com o Migrante, onde se espera o estabelecimento de uma prática migratória isenta 
dos preconceitos e da discriminação consoante persiste na prática. Mas tal não há de acontecer e/ou continuar.

De acordo com Cotinguiba e Cotinguiba (2014, p. 64 - 65), a emigração haitiana em terras brasileiras é multifacetada, possui dinâmica que deve ser ressaltada, para que haja uma melhor compreensão e aceitação deste impactante fenômeno migratório, uma vez que pesquisas e dados estatísticos revelam que apresenta fortes indícios culturais.

Neste norte, consigna-se que trata-se de aspiração do povo haitiano a possibilidade de estudar em outros países, como forma de valorização profissional, pessoal, familiar e também, na expectativa de retornar e poder auxiliar financeiramente parentes e amigos. Eis um dos motivos porque muitos vieram para o Brasil na última década, na perspectiva de melhorar sua própria condição de vida e com isto facultar a reparação da qualidade de vivência de seus familiares que se se encontram no Haiti; Outro pretexto consiste na "notícia" de oferta de empregos e possível colocação em serviços por aqui, com isso, “[...] conseguem enviar dinheiro, viajar, levar presentes e mesmo conseguir trazer a família para o Brasil." (COTINGUIBA; COTINGUIBA, 2014, p. 65).

Assinalam Zamberlam et al (2014, p. 60) que, entre os motivos da emigração, a grande maioria das pessoas encontra-se em "[...] busca de trabalho por um futuro melhor para si e a família (81,6\%)." Esta causa é acompanhada de outros como: “[...] informações de amigos que já estavam no Brasil e o bom acolhimento e a busca de estudo." Acrescentam ainda os autores:

Apontam também como motivação o crescimento e desenvolvimento econômico de cidades que já acolheram haitianos, fazendo com que estes sejam protagonistas para novas levas. A relativa estabilidade econômica do Brasil tem favorecido a expansão empresarial que busca trabalhadores imigrantes independente de qualificação.

Já, os parâmetros de cunho dito "racistas" instalados na sociedade têm a dimensão de construções históricas, políticas e sociais, e servem de pretexto para separar os homens, dentre os seus pares. A origem das desigualdades está muito mais no tratamento político e muito menos na função de cidadania que cada um conserva. Ambas requerem um acontecer, sem o qual, dado em um ponto da história, não formulariam os espaços sociais, e o reconhecimento da democracia, e, consequentemente, dos sujeitos de direitos. 
O desmantelamento das práticas racistas, mantenedoras de sua própria ideologia, requer uma mudança - anúncio dela, para que, desta forma se possa denunciá-las, uma vez, uma vez mais, e outra vez se preciso.

No dizer de Touraine (2007, p. 35),

Quando os membros de uma sociedade se definem pela própria capacidade e vontade de mudar ao invés de manter uma ordem estabelecida, eles não podem mais ser definidos apenas pela sua pertença social. Um ator social nasceu. Mas ele é muito mais do que a consciência de si vista separadamente da consciência dos outros; ele carrega consigo a idéia de direito à liberdade e à criação, de um direito natural que pertence a todos. $\mathrm{E}$ a afirmação destes direitos significa que os indivíduos implicados sentem-se participantes das iniciativas que estimulam a sociedade a se transformar [...].

O universo da cor, da feição e da aparência não pertence, na verdade, ao universo da teoria humana, não nasce da teoria jurídica, não é derivada de grandes pensadores ou façanha de grandes estrategistas. Essa ideia é nascida paralela à justiça, fora dela, que depois se aloja em uma prática dos justos, por conta de uma mesma prática que tem por intuito proteger o homem de bem e que, por sinal, requer controles sociais em prol de um sistema de trocas, de demanda de grupos e exercício de poder, o que, possivelmente, mantém a materialidade e a riqueza.

Historicamente as ideologias racistas - e não a de classes - ingressou no palco da política, acompanhando as nações europeias quando os povos europeus preparavam seu corpo político. O racismo adentrou todas as fronteiras, definidas por padrões geográficos, linguísticos ou quaisquer outros e negou a existência político-nacional, até se transformar em arma que destruiria a nação (ARENDT, 1989, p. 191).

No mundo ocidental a escravatura sedimenta em grande parte uma forma de obrigar a subordinação a uma raça (os da raça negra) a um povo (historicamente, com formação democrática - os brancos). Entretanto, a identificação da expressão raça não é de todo acurada na contemporaneidade.

Apenas, de forma superficial se pode conhecer a história dos povos e tribos préhistóricos, no entanto, “o termo raça só chega a ter um significado preciso, quando e onde os povos com história conhecida se defrontam com tribos das quais não têm nenhum registro histórico e que ignoram a sua própria história” (ARENDT, 1976, p. 102).

No Brasil, a escravatura concebe um dos fenômenos mais ilustrativos da concepção e fundamentos do racismo. A escravidão teve início com a cana de açúcar, no Século XVI, e, simbolicamente terminou com a assinatura da Lei Áurea em 1888 e 
envolveu na sua maioria absoluta os representantes da cultura africana que foram retirados à força de seu país de origem. De qualquer forma, tal movimento é singularmente representativo, mas não se pode olvidar as demais fontes que compuseram a história desta Nação, notadamente os habitantes originários - os índios, os colonizadores e imigrantes (árabes, judeus, italianos e alemães, sem pretender esgotar os exemplos).

Daqui decorre ser apontada a distinção que alguns fazem em torno da xenofobia e do racismo. O termo xenofobia indica o fenômeno, que teria sido observado em todos os tempos e em todas as sociedades, da incompreensão e das hostilidades que manifestariam espontaneamente nos homens em relação ao Outro. O racismo teria pretensão científica em função de critérios biológicos de algumas categorias de populações no interior de sua própria sociedade; típico da sociedade ocidental (SCHNAPPER, 2003, p.456).

Considera-se provável a referência do agir que discrimina ao modo de pensar que produz e instala o preconceito, e após, age com um viés cuja característica é percebida com a qualidade discriminatória.

Este ponto, consoante indicado na introdução deste capítulo usufrui de particular relevância. É que, o tratamento dispensado ao migrante, entendido este como apátrida, imigrante e/ou refugiado, dado que o estabelecimento dessas relações, inclusive quanto à mulher, tem sido afetado pelo preconceito e pela discriminação.

Inicia-se com uma ilustração, eis que a mesma muito tem a contribuir em torno da reflexão quanto ao binômio discriminação-preconceito, os quais são discorridos por Sartre (1978, p.7 e 94):

Além disso, mostra-nos que o anti-semitismo, sob suas formas mais temperadas, mais evoluídas, permanece uma totalidade sincrética que se expressa através de discursos de feição razoável, mas suscetível de levar até a modificações corporais. Certos homens são tomados de súbita impotência se ficam sabendo que a mulher com quem dormem é judia. Há em certa gente, o asco ao judeu, assim como há o asco ao chinês ou ao negro. E esta repugnância não nasce do corpo, pois se pode amar perfeitamente uma judia, se se ignora sua raça; tal repulsa chega ao corpo pelo espírito, é um compromisso da alma, mas tão profundo e tão completo que se estende ao fisiológico, como sucede na histeria. (1978, p.7). [...] Aos que durante séculos, tentaram debalde porque era negro, reduzi-lo ao estado de animal, é preciso que êle os obrigue a reconhecê-lo como homem. Ora, no caso não há escapatória, nem subterfúgios, nem "passagem de linha" a que possa recorrer; um judeu, branco entre os brancos, pode negar que seja judeu, declararse homem entre homens. O negro não pode negar que seja negro ou reclamar para si esta abstrata humanidade incolor: êle é prêto. (1978, p. 94) 
Recorre-se também à indicação seguinte, certa de que a dinâmica do fenômeno migratório no espaço das relações humanas requer o enfrentamento de seu próprio modelo, a vista de reparar a discriminação e o preconceito. Senão, veja-se! ${ }^{3}$

A "janela de Johari", (LUFT; INGHAM, 1955) bem pode auxiliar a demonstração de tal problemática:

$1^{a}$ vidraça - "Área livre ou eu aberto", zona que integra conhecimento do ego e também dos outros; ou, o que eu reconheço sobre mim e que os outros também reconhecem;

$2^{\mathrm{a}}$ vidraça - "Área cega ou eu cego" - zona de conhecimento apenas detido pelos outros e, portanto, desconhecido do ego; ou, o que os outros reconhecem e eu não reconheço sobre mim;

$3^{a}$ vidraça - "Área secreta ou eu secreto" - zona de conhecimento pertencente ao ego e que não partilha com os outros; ou, o que eu reconheço sobre mim e os outros não reconheçam;

$4^{\mathrm{a}}$ vidraça - “Área inconsciente ou eu desconhecido" - zona que detêm os elementos que nem o ego, nem os outros têm consciência ou conhecimento, ou aquilo que eu sou, que eu não reconheço e que ninguém reconheço. Esta representa $90 \%$ das vezes.

Desta forma, o modo de pensar na dimensão do preconceito e da discriminação, acontece sempre, inicialmente, na dimensão do eu, assim sendo, desencadeiam-se na $1^{\mathrm{a}}$ e $3^{\mathrm{a}}$ janela, mas seus efeitos são sentidos em todas elas, sendo que na $1^{\mathrm{a}}$ vidraça a igualdade, e as relações jurídicas são reconhecidas e, na $3^{\mathrm{a}}$ o estado de direito e igualdade se faz sentir, na dimensão do outro, mas o eu não os reconhece. Logo, o eu, eventualmente pode conceber a discriminação e eventualmente exercê-la. Na $2^{\mathrm{a}}$ vidraça, há uma igualdade para os outros, mas não para o eu e, inexiste a discriminação. A $4^{\text {a }}$ vidraça representa o lugar onde o estado de igualdade entre os sujeitos e as instituições devem chegar, preventivamente, e, deste modo, sob a lógica do pensamento é onde $90 \%$ das vezes se estão.

\footnotetext{
${ }^{3}$ A construção deste estudo sobre o preconceito e a discriminação, tem por norte as reflexões de ROSSETTO, Geralda Magella de Faria. Relações raciais e os desafios do princípio da igualdade, p. 293 - 318. 4 Expressão criada por Joseph Luft e Harrington Ingham, resultante da união das primeiras sílabas dos nomes de seus criadores.
} 
Compreende-se que a primeira consideração parte do sentido de que o que me incomoda eu percebo no outro, desencadeando em mim um agir, no caso um agir discriminador.

A sociedade cada vez mais dá conta das diversidades, quer de comportamentos, quer de valores, quer de culturas, quer de direitos. Ora, entre si e com os outros deve-se reciprocamente o respeito e a tolerância. Sobre a questão, Schnapper (2003, p. 457), afirma que a era contemporânea pretende uma sociedade moderna, racional, baseada segundo uma ordem humana autônoma, fundada sobre o indivíduo. Ela recalca o sentimento de hierarquia, que permanece no ,impensado ${ }^{e e}$ da concepção da ordem global.

Na relação dialógica se apresenta o social e o individual, e, da relação no (e com o) Estado, sobressaem a democracia e a cidadania. Dessa concepção, tem-se

O fato de terem sido formulados, ao mesmo tempo os princípios da democracia e da cidadania, e por outro lado, de se terem conhecido os horrores do século XIX e mais ainda do Século XX, alguns dos quais perpetrados em nome de uma teoria racista, levou a interrogar sobre a ligação entre a legitimidade política moderna e o racismo. Estaria o racismo intrinsecamente ligado ao projeto da democracia liberal e da nação, esta última sendo por natureza necessariamente nacionalista? Será que a democracia liberal, qualificada de capitalista pela própria natureza, segundo a expressão Wallerstein, o racismo (Balibar \& Wallerstein, 1988, p. 50)? (SCHNAPPER, 2003, p. 457).

Ora, tais ponderações permitem referir "o problema da ligação entre os princípios da modernidade política e o racismo", e conseqüentemente afirmar que "o racismo moderno inscreve-se nas próprias relações sociais, indissociáveis das estruturas do mundo capitalista" (SCHNAPPER, 2003, p. 457).

A segunda consideração parte da premissa de que o que eu não enxergo em mim e está em crise, eu busco no outro, no diferente, uma maneira de apontar alguém e mudar o centro da atenção.

A terceira consideração parte da afirmação de que a criação do preconceito podese dar além dos indivíduos. É a sociedade que cria tais percepções construindo suas relações de poder.

A quarta consideração parte do sentido de que não se quer enxergar o ser como partícipe da discriminação e do preconceito, apesar de contribuir (querendo ou não) para sua estruturação simbólica e, posterior manifestação. Ora, o que é neutro pode estar favorecendo alguém. Favorece-se alguém inexiste neutralidade e, inexistindo, ocorre de não reconhecer a si, o outro ou os benefícios que dali poderia advir. Este é o caso da $4^{\mathrm{a}}$ vidraça. 
Entretanto, é preciso dizer, potencialmente, há uma extraordinária combinação, a dimensão política, a legislativa e a jurídica, unidas, as três compõem o estado da questão cases and controversies - e, é por meio deles, que se oportunizam os pressupostos para o contato com a comunidade e seus problemas.

Segundo a concepção jurídica, discriminar significa prejudicar, anular e restringir direitos em razão de diferenças de raças, cor, gênero, origem nacional ou étnica que tenha o propósito ou o efeito de anular ou prejudicar o reconhecimento, o gozo ou exercício de Direitos Humanos e liberdades fundamentais, e nesta dimensão impedir o tratamento formal igualitário (RIOS, 2007).

Frente a tais considerações é prudente ponderar que a discriminação em si não é um fato de simples conduta. Cada vez mais a sua atitude afeta a democracia e o estado de direito. "A razão é simples, a Democracia pressupõe tolerância. Não pode haver regime democrático quando exigimos que nossos interesses e valores sejam aceitos como absolutos; não haverá democracia se formos incapazes de conviver com a diversidade, com os valores do „outro ${ }^{\text {ee” }}$ (SILVA, 2008, p. 141).

As constituições e as Declarações de Direitos firmadas dão conta de que a discriminação racial é proibida. A Constituição da República Federativa do Brasil de 1988 confirma referida tradição nos arts. $3^{\circ}, \mathrm{IV} ; 5^{\circ}$, I e XLII e $7^{\circ}, \mathrm{XXX}^{5}$.

Ademais, convém realçar o seguinte aspecto, o fato de que o Estado Brasileiro não aceita a deliberação, via Emenda, tendente a abolir os direitos e garantias individuais. Isto significa, nos termos do art. 60, IV, da CRFB/1988, que à nação brasileira impõe o respeito e o cumprimento do tratamento igualitário, quer na dimensão organizacional política, social, e no estabelecimento de convívio individual.

Não se pode com isto ter a crença de que a determinação sozinha do texto constitucional terá o condão de traduzir em medidas efetivas em prol do término da discriminação nos casos de racismo. Isto também deve ser lido na dimensão do princípio da

\footnotetext{
${ }^{5}$ Constituição Federal, art. $3^{\circ}$. Constituem objetivos fundamentais da República Federativa do Brasil: [...] IV

- promover o bem de todos, sem preconceitos de origem, raça, sexo, cor, idade e quaisquer outras formas de discriminação. Art. $5^{\circ}$ Todos são iguais perante a lei, sem distinção de qualquer natureza, [...] I - Homens e mulheres são iguais em direitos e obrigações, nos termos desta Constituição; [...]; XLII - A prática do racismo constitui crime inafiançável e imprescritível, sujeito à pena de reclusão, nos termos da lei; Art. $7^{\circ}$. São direitos sociais dos trabalhadores urbanos e rurais, além de outros que visem à melhoria de suas condições sociais: [...] XXX - proibição de diferenças de salários, de exercício de funções e de critérios de admissão por motivo de sexo, idade, cor, ou estado civil.
}

Revista de Direitos Humanos e Efetividade | e-ISSN: 2526-0022 | Minas Gerais | v. 1 | n. 2 | p. 236 - 259 | Jul/Dez. 2015. 
igualdade, e mesmo articulado juridicamente, consegue-se minimamente dar conta dos fundamentos jurídicos.

A transformação social que no Estado contemporâneo apresenta diversas faces tem agora de enfrentar uma grande façanha - a de implementar a justiça social, pelo viés da humanidade, redimensionando o conteúdo dos Direitos Humanos.

Frente a um Estado ausente, um Estado presente, neste sentido esclarece Rocha (1990, p. 41):

O Estado não pode criar legalidades discriminatórias e desigualadoras, nem pode deixar de criar situações de igualação para depurar as desigualdades que se estabeleceram na realidade social em detrimento das condições iguais de dignidade humana.

Há ainda nesta questão um terceiro aspecto, o qual ao lado do ponto do preconceito e da discriminação, do estabelecimento das relações humanas, que neste foi objeto da ilustração de Johari e das indicações de Sartre, e do número de pessoas envolvidas nesse processo, vem compor a tríade do fenômeno migratório no contexto ora apresentado por este estudo. É importante o registro, na medida em que visivelmente o fenômeno migratório cada dia mais passa a deter importância pela quantidade dos envolvidos e pela qualidade com que a dinâmica está a cobrar das autoridades visando oferecer o conforto da proteção dos direitos abrangidos.

O número de habitantes brasileiros, segundo consta no site do $\mathrm{IBGE}^{6}$, é de cerca de 204.608.000 habitantes, desse universo, quantos são pertencentes ao grupo dos refugiados e dos imigrantes (?). A construção desse dado é sobremaneira importante porque está a revelar: a) a migração legal ou regular de pessoas; b) a migração ilegal ou irregular em busca de trabalho; c) o tráfico de pessoas ou, ainda, de outra forma, tem-se a formulação de políticas para refugiados, a escolha, seleção e elegibilidade das mesmas, e também a integração local e regional de refugiados. A lei garante documentos básicos aos refugiados e imigrantes, mas é o pertencimento ao território nacional que fará a diferença na relação migratória.

De acordo com o $\mathrm{CONARE}^{7}$, a realidade numérica do Brasil, quanto ao fenômeno da migração, é a seguinte:

\footnotetext{
${ }^{6}$ Disponível em: 〈http://www.ibge.gov.br/apps/populacao/projecao/>. Acesso em: 01 agos. 2015.

${ }^{7}$ Comitê Nacional para os Refugiados (CONARE), órgão interministerial presidido pelo Ministério da Justiça e que da formulação de políticas para refugiados no país, com a elegibilidade, mas também com a integração
} 
[...] o Brasil possui na atualidade (em outubro de 2014) 7.289 refugiados reconhecidos, de 81 nacionalidades distintas (25\% deles são mulheres) incluindo refugiados reassentados. Os principais grupos são compostos por nacionais da Síria, Colômbia, Angola e República Democrática do Congo (RDC). Este perfil vem mudando gradualmente desde 2012, quando o país adotou uma cláusula de cessação de refúgio aplicável aos angolanos e liberianos, com base em orientação global expedida pelo ACNUR em junho do mesmo ano. Conforme a portaria do Ministério da Justiça n ${ }^{\circ} 2.650$ (de outubro de 2012), estes estrangeiros estão recebendo a residência permanente no país, em substituição ao status de refugiado. [...] Com base em dados do CONARE referentes ao período entre janeiro de 2010 e outubro de 2014, o ACNUR elaborou uma análise estatística que demonstra o fortalecimento continuado da proteção aos refugiados e solicitantes de refúgio no Brasil. O número total de pedidos de refúgio aumentou mais de $930 \%$ entre 2010 e 2013 (de 566 para 5.882 pedidos). Até outubro de 2014, já foram contabilizadas outras 8.302 solicitações. A maioria dos solicitantes de refúgio vem da África, Ásia (inclusive Oriente Médio) e América do Sul.

Também, merece distinção o fato de que "O número total de pedidos de refúgio aumentou mais de $930 \%$ entre 2010 e 2013 (de 566 para 5.882 pedidos). Até outubro de 2014, já foram contabilizadas outras 8.302 solicitações. A maioria dos solicitantes de refúgio vem da África, Ásia (inclusive Oriente Médio) e América do Sul. ${ }^{8}$

A realidade é tal que o trabalho empreendido pelo Estado brasileiro e seus organismos, em breve síntese, operam prestando assistência humanitária, e são responsáveis pela proteção e integração de refugiados ${ }^{9}$, sendo que,

Em 2014, a maioria das solicitações de refúgio no Brasil foi apresentada em São Paulo (26\% do total de solicitações no período), Acre (22\%), Rio Grande do Sul (17\%) e Paraná (12\%). Regionalmente, estão concentradas nas regiões Sul (35\%), Sudeste $(31 \%)$ e Norte $(25 \%) .{ }^{10}$ [...] o CONARE reconheceu solicitações de refúgio de 18 países diferentes, como Síria, Líbano, RDC e Mali, demonstrando sensibilidade às principais crises humanitárias da atualidade. Desde 2013, praticamente $100 \%$ das solicitações apresentadas por nacionais da Síria foram reconhecidas. Entre os refugiados reconhecidos pelo Brasil, os sírios representam o maior grupo, com 20\% do total. Em seguida estão os refugiados da Colômbia, de Angola e da República Democrática do Congo. Outras populações relevantes são os refugiados do Líbano, Libéria, Palestina, Iraque, Bolívia e Serra Leoa. Até setembro deste ano, existem 8.687 casos ainda em tramitação no CONARE,

local de refugiados. Disponível em: 〈http://www.acnur.org/t3/portugues/recursos/estatisticas/dados-sobrerefugio-no-brasil>. Acesso em: 01 agos. 2015.

8 Disponível em: <http://www.acnur.org/t3/portugues/recursos/estatisticas/dados-sobre-refugio-no-brasil >. Acesso em: 01 agos. 2015.

${ }^{9}$ Estes dados não incluem informações relacionadas aos nacionais do Haiti que chegaram ao Brasil desde o terremoto de 2010. Apesar de solicitarem o reconhecimento da condição de refugiado ao entrarem no território nacional, seus pedidos foram encaminhados ao Conselho Nacional de Imigração (CNIg), que emitiu vistos de residência permanente por razões humanitárias. De acordo com dados da Polícia Federal, mais de 39.000 haitianos entraram no Brasil desde 2010 até setembro de 2014.

10 Disponível em: <http://www.acnur.org/t3/portugues/recursos/estatisticas/dados-sobre-refugio-no-brasil>. Acesso em: 01 agos. 2015. 
sendo 2.164 do Senegal, 1.150 da Nigéria, 1.090 de Gana e 571 da República Democrática do Congo. Dentre o total de solicitações pendentes, 41 foram submetidas em 2011, 176 em 2012, 1.340 em 2013 e 7.130 em 2014. Comprometido com o princípio da solidariedade internacional, o Brasil tem exercido papel fundamental no desenvolvimento e implantação do Programa de Reassentamento Solidário na América Latina, como parte do Plano de Ação do México. Desde 2002, o Brasil reassentou mais de 612 refugiados (colombianos, em sua maioria), dentre os quais $46 \%$ são mulheres. Também há grupos de refugiados vindos de outros continentes. Em 2014, foram aceitos no Programa de Reassentamento refugiados do Sri Lanka e da Síria. Nos próximos anos, o Brasil planeja expandir seu programa de reassentamento para um maior número de casos extracontinentais, de modo a oferecer acolhida para refugiados deslocados de outras regiões.

A realidade brasileira é digna de realce e tem merecido destaque pela condução e distribuição dos trabalhos que têm sido empreendidos e concluídos quanto à temática. Neste sentido, “[...] o país sediou um encontro governamental onde 18 países da América Latina se comprometeram a se engajar mais na proteção das vítimas de deslocamentos forçados e de apátridas na região", tendo sido firmadas a "Declaração de Brasília para Proteção de Refugiados e Apátridas nas Américas", bem como, do resultado de sua liderança dentro do MERCOSUL, ao final de 2012, foi assinada a "Declaração de Princípios Internacionais de Proteção dos Refugiados", sendo que, referido "documento reafirma o princípio da não devolução (non-refoulement), a importância da reunificação familiar e a priorização das abordagens de idade, gênero e diversidade. A Declaração também enfatiza a importância de se evitar políticas migratórias restritivas e a necessidade de estabelecer mecanismos de cooperação adicionais e novas formas complementares de proteção humanitária", culminando conquanto anotado "com adoção da Declaração e Plano de Ação do Brasil, que renovará os compromissos da região frente aos refugiados e apátridas durante a próxima década”.

Diante do exposto, sob a lógica do "micro" e do "macro" o fenômeno migratório se dá seguindo um padrão de laço familiar para depois alcançar o espaço global, quais sejam, primeiramente inicia por meio de emigração para outras regiões, depois de lado a lado de migrações intra-regionais e assim, seguindo uma escala circular até retomar a reunião de laços familiares, que tem sido a principal causa da regularização migratória.

\section{CONSIDERAÇÕES FINAIS}

11 Disponível em: <http://www.acnur.org/t3/portugues/recursos/estatisticas/dados-sobre-refugio-no-brasil >. Acesso em: 01 agos. 2015. 
Os Direitos Humanos, cuja afirmação histórica, data, notadamente da $2^{\mathrm{a}}$ Guerra Mundial, foram refletidos em torno do impacto da globalização, quer seja a temática da mobilidade migratória, buscando apresentar as dificuldades que se apresentam decorrentes de sua fundamentalidade, na perspectiva de um consenso universal.

Como arremate deste ensaio, convém assinalar que a superação das dicotomias voltadas para o universalismo e o multiculturalismo como ponto de análise dos Direitos Humanos, somente devem ser adotados como modelo, se enfrentados na dimensão da globalização, se esta for empreendida sob o referencial de ser comum a todas as culturas, a todos os catálogos de direito, mas que possam ser integradas no sistema global.

O fenômeno migratório não é algo novo no Brasil, contudo tem chamado a atenção da população, pelo viés entorpecedor, especialmente, quando fluem de forma abrupta as mais diversas formas de preconceito e discriminação dos nacionais, esquecendo-se estes, que quase sua totalidade tem como origens migrantes europeus e asiáticos.

Esta nova, por assim dizer, grande onda de mobilidade migratória, ocasionou um repensar as políticas públicas, que estavam adormecidas, desde o período militar da política brasileira, bem como fez com que se observassem os Direitos Humanos, por um viés universal e globalizado, redimensionando esta concepção com o intuito específico em abarcar as diversidades culturais que caracterizam os povos.

Neste interim, o estudo apresentou particularidades da população haitiana, cujo fluxo para o território brasileiro, ocorreu, notadamente, em vista da missão de paz que o Brasil assumiu perante aquele país, pela queda do governo haitiano e a ajuda humanitária após o fatídico terremoto que ceifou milhares de vidas e assolou o Haiti em 2010.

Os migrantes quando aqui se encontram, enfrentam inúmeras barreiras ao procurarem as instituições públicas brasileiras, em face da ausência de políticas públicas migratórias adequadas às demandas da contemporaneidade, em especial, para o acesso aos direitos sociais, inerentes e equitativos à condição de qualquer cidadão.

Se há uma particularidade que confere identidade à migração nos dias atuais, esta se deve ao apoio familiar que tem sido dedicado à saída e/ou vinda de um de seus familiares, via de regra, do sexo masculino, o qual é selecionado, dentre os componentes do ambiente familiar, por ser eleito como possuidor das características ideais para obter um trabalho, no destino para onde irá se transferir e/ou morar. Este "modelo" detém uma característica sui generis, diferenciadora de outras épocas, onde o fenômeno da migração 
foi imposto, como, ocorreu no Brasil, quando da escravidão ocorrente nos Séculos XVIIXVIII.

Na extensão da teoria racista, a construção de sua (des) igualdade, se faz pelo modo de compreender, de (re) conhecer, de olhar, de observar o Eu e o Outro, e, a partir do modo de pensar, excluir, discriminar, instalando as (des)sigualdades, permanentes e definitivas.

Por fim, foi analisada a tradução da normatividade perante o Texto Constitucional e o (re) conhecimento da discriminação racial, contrapondo estas duas fontes, o que, de nada adiantaria a promoção, defesa e proteção dos Direitos Humanos, seja pelo ordenamento jurídico brasileiro ou pelos tratados internacionais, se houver a insistência na instalação de tantas desigualdades arbitrárias, e, sobretudo, se não puder ser compreendidas as amarras ideológicas em torno da discriminação racial.

A tendência é pela negativa do racismo, justamente pela dificuldade de reconhecêlo em sua concretude. Discrimina-se, sem admitir as atitudes inerentes ao agir preconceituoso da separação das raças. Nesta perspectiva, há uma construção ideológica, de neutralidade, de desconfiança e de desprezo para com o Outro, tão disfarçados quanto concretas a dissimulação, o preconceito, a discriminação, a não inclusão nas políticas públicas ou mesmo sua inércia, por isto mesmo, carecendo de amplo reconhecimento do estatuto jurídico dos migrantes, e, sobremaneira de particular proteção, promoção e defesa dos Direitos Humanos, independentemente de raça, cor ou nacionalidade.

\section{REFERÊNCIAS}

ARENDT, Hannah. A condição humana. (Trad. Roberto Raposo). Rio de Janeiro: Forense, 1989.

ARENDT, Hannah. As origens do totalitarismo: imperialismo, a expansão do poder uma análise dialética. (Trad. Roberto Raposo). Rio de Janeiro: Documentário, 1976.

BOBBIO, Norberto. A era dos direitos. (Trad. Nelson Coutinho). 19. tir. Rio de Janeiro: Campus, 1992.

BRASIL. Constituição de 1988. Constituição da República Federativa do Brasil: promulgada em 05 de outubro de 1988. Disponível em: http://www.planalto.gov.br/ccivil_03/Constituicao/Constituicao34.htm> Acesso em 24 jul. $\underline{2015}$. 
CARTA ENCÍCLICA. Laudato si'. Sobre o Cuidado da Casa Comum. Santo Padre Francisco. Roma: Tipografia Vaticana, 2015.

COTINGUIBA, Marília Lima Pimentel; COTINGUIBA, Geraldo Castro. Imigração haitiana para o Brasil: os desafios no caminho da educação escolar. Revista pedagógica, Chapecó, v.17, n.33, p. 61-87, Jul./Dez. 2014.

FREEMAN, Michael. Direitos Humanos universais e particularidades nacionais. In: Seminário de direitos humanos no século XXI. (Trad.) Janete Ferreira Carneiro. Rio de Janeiro, $\quad 10 \quad$ e $\quad 11$ 09/1998. Disponível em: http://www2.mre.gov.br/ipri/Papers/DireitosHumanos/Artigo12.doc. Acesso em: 09 dez. 2007

GONZÁLEZ, Rodrigo Stumpf. A Retórica dos Direitos Humanos. In: Constituição, sistemas sociais e hermenêutica. SANTOS, André Leonardo Copetti; STRECK, Lênio Luiz; ROCHA, Leonel Severo (Org.). São Leopoldo: Unisinos, 2006, p. 165-179.

KÜNG, Hans. Uma ética global para a política e a economia mundiais. Petrópolis, RJ: Vozes, 1999.

LUFT, Joseph; INGHAM, Harrington, The Johari Window, a Graphic Model for Interpersonal Relations, Los Angeles, University of California,(UCLA), Western Training Laboratory for Group Development, 1955.

MARTINEZ, Gregório Peces-Barba. Derecho y derechos fundamentales. (Colección "El Drecho y la justicia”, dirigida por Elias Díaz). Madrid: Centro de Estúdios Constitucionales, 1993.

MORAIS, José Luis Bolzan de. Direitos Humanos "globais (universais)", de todos, em todos os lugares. In: Anuário do programa de pós-graduação em direito. ROCHA, Leonel Severo; STRECK, Lênio Luiz. São Leopoldo: Unisinos, 2001, p. 43-76.

PIOVESAN, Flávia; IKAWA, Daniela (Coord.). Direitos humanos: fundamento, proteção e implementação - perspectivas e desafios contemporâneos. V.II. Curitiba: Juruá, 2007.

RAMOS, André de Carvalho. Direitos humanos em juízo. São Paulo: Max Limonad, 2001.

ROSSETTO, Geralda Magella de Faria. Relações raciais e os desafios do princípio da igualdade. In: CUSTÓDIO, André Viana; VIEIRA, Reginaldo de Souza (Org.). Estado, política e direito - Políticas públicas e direitos sociais. V. 3. Criciúma: Unesc, 2011, p. $293-318)$.

RIOS, Roger Raupp. In: Direitos Humanos e Discriminação. 3. Jornada da justiça federal. Criciúma, Auditório Rui Hülse, 05 nov. 2007.

ROCHA, Carmen Lúcia Antunes. O princípio constitucional da igualdade. Belo Horizonte: Jurídicos lê, 1990. 
SARTRE, Jean-Paul. Reflexões sobre o racismo: I Reflexões sobre a Questão Judaica, II Orfeu Negro. (Trad. J. Guinsburg). 6. ed. Rio de Janeiro/São Paulo: Difel, 1978.

SCHNAPPER, Monique. Dicionário de ética e filosofia moral. (Org. Monique Canto Sberber. (Trad. Ana Maria Ribeiro-Althof, Magda França Lopes, Maria Vitória Kessler de Sá Brito Paulo Neves). São Leopoldo: Unisinos, 2003.

SILVA, Ovídio Araújo Baptista da. Jurisdição, direito material e processo. Rio de Janeiro/ São Paulo: Revista dos Tribunais, 2008.

TOURAINE, Alain. O mundo das mulheres. (Trad. Francisco Moráz). Petrópolis: Vozes, 2007.

TRINDADE, Antonio Augusto Cançado. O Legado da Declaração Universal e o Futuro da Proteção Internacional dos Direitos Humanos. In: O cinquentário da Declaração Universal dos Direitos do Homem. (Orgs) AMARAL JR, Alberto do; PERRONEMOISÉS, Cláudia. São Paulo: Ed. da Universidade de São Paulo, 1999, p.13-54.

VENTURA, Deisy; REIS, Rossana Rocha. Criação de lei de migrações é dívida histórica do Brasil. (Grupo de Reflexão sobre Relações Internacionais). Publicado em 21/08/2014, 04h38 In: Carta capital. Disponível em: < http://www.cartacapital.com.br/sociedade/divida-historicauma-lei-de-migracoes-para-o-brasil-9419.html>. Acesso em 01 agos. 2015.

VIENA. Conferência mundial sobre direitos humanos, 1993. Disponível em: <http://www.pge.sp.gov.br/centrodeestudos/bibliotecavirtual/instrumentos/viena.htm>. Acesso em: 02 dez. 2007.

ZAMBERLAM, Jurandir et al. Os novos rostos da imigração no Brasil: haitianos no Rio Grande do Sul. Porto Alegre: Solidus, 2014. 